\title{
US Strategy in a Changing World Order: Challenges for Russia
}

\author{
F. G. Voitolovskii ${ }^{\#}$ \\ Primakov National Research Institute of the World Economy and International Relations (IMEMO), \\ Russian Academy of Sciences, Moscow, Russia \\ e-mail: seadog@imemo.ru
}

Received April 16, 2021; revised April 16, 2021; accepted April 22, 2021

\begin{abstract}
The article covers the impact of changing global economic and political order on the attitudes and narratives of US elites and decision-makers upon America's global leadership, its forms and practicies. The author shows how the economic, political, and ideological prerequisites for changing the position of the United States in the world affect the foreign policy ideology and practice of Democratic and Republican administrations, as well as Washington's approaches to the development and implementation of a national security strategy. Particular attention is paid to the approaches of the US government to relations with China and Russia. The key trends in American policy towards Russia during the administrations of B. Obama, D. Trump, and the first months of the presidency of J. Biden are examined.
\end{abstract}

Keywords: United States, foreign policy, US strategic national security, US-PRC relations, Russia-US relations, international security, global competition, interdependence.

DOI: $10.1134 / \mathrm{S} 1019331621040080$

Over the past $10-15$ years, the US leadership, regardless of which administration was in powerDemocratic or Republican-has consistently solved the same strategic task-the long-term preservation of American global leadership. The US leadership at the level of strategic documents has repeatedly formulated the need to maintain it and resist attempts to question it. Washington seeks to oppose any regional and global processes and actions of other powers that undermine American power and influence in certain areas. The goal of maintaining the leading position of the United States in international politics, the world economy, and in the field of global security has become an important part of the foreign policy rhetoric of presidents, secretaries of state, and other officials. The very formulation of such a task is due not only to the subjective characteristics of the messianic foreign policy tradition, but also has substantial economic and political foundations.

\section{STRATEGIC GOAL: TO PRESERVE US LEADERSHIP}

The American establishment realized and formulated the need to solve this essentially ideological problem at the doctrinal level immediately after the end of the Cold War-at that time there were no signif-

\footnotetext{
\# RAS Corresponding Member Fedor Genrikhovich Voitolovskii is Director of the Primakov IMEMO, RAS.
}

icant obstacles to its solution. Then the situation in the world began to change, and the American leadership faced new internal and external challenges. The world began changing faster than the representatives of the American elite could have imagined after the end of the confrontation with the Soviet Union, which was interpreted as a victory for the United States and its allies, as well as their ideas and values. For the most part, these transformations have contributed to the reduction of opportunities for undivided American dominance. In contrast to the 1990s-2000s, which in the American political science literature and journalism are usually called the "unipolar moment," ${ }^{1}$ when American power seemed undivided and eternal, the United States is increasingly faced with growing competition from other leading powers. Over the past decade, the role of the PRC has become key here, the economic and political influence of which has gone beyond the APR.

The illusions of the American expert community and establishment of the 1990s about the lack of alternatives and unending period of US leadership in the development of globalization processes and the formation of institutions, norms, and principles of global governance melted away in the 2010s under the influence of objective changes that took place in the world

\footnotetext{
${ }^{1}$ This term was first introduced by the American political publicist Charles Krauthammer in 1991 in an article of the same title [1].
} 
economy and were associated with strengthening of new centers of its development. The global financial and economic crisis of 2008-2010 played an important role in this, the source of which was the US economy and the actions of American financial regulators. Then, for the first time, the belief of the elites of other countries in the stability of not so much the American economy-it practically recovered after a few years thanks to the successful overcoming of the crisis and recession-as in the power of the US national institutions was shaken for the first time [2].

Attempts taken in the 2000s by the Republican administrations of George W. Bush to build "peace through strength" [3] and to consolidate the special status of the United States based on the creation of a monopoly on the use of military force on a global scale also faced significant restrictions, primarily of an internal nature. The American taxpayer was not ready to bear the costs of the involvement of the US armed forces and their allies "overseas." The determining factor here was the financial and economic crisis of 2008-2010, and the ensuing recession, and then the politically and ideologically motivated desire of the Obama administration to end unpopular military campaigns and redistribute government spending in favor of solving social problems.

In addition, American society psychologically found it difficult to cope with the death of its fellow citizens in Afghanistan and Iraq, as well as with the social and other problems of veterans. Since 2001, more than three million American troops have gone through these wars. On the one hand, this gave the US armed forces invaluable combat, transport, logistics, organizational, and psychological experience, and on the other hand, for the first time after the Vietnam War, Americans faced problems such as death, injury, and mutilation of American servicemen abroad, posttraumatic stress disorder, and psychological and social problems of veterans and their families. The cost of the war in Afghanistan in the period from 2001 to 2019 in terms of military spending exceeded $\$ 778$ billion. In addition, the expenditures of the US state budget for assistance in state building in this country; the creation of infrastructure, a new Afghan army, and police; and the solution of humanitarian problems exceeded \$2 trillion [4]. The military campaign in Iraq, as well as programs to help restore statehood in this country from 2003 to 2019 cost the US state budget practically the same- $\$ 838$ billion in military spending and about $\$ 2$ trillion in aggregate with other expenses [5]. The main political outcome of the two extremely costly military campaigns was the decline of the United States' prestige as a superpower capable of solving any problems of global and regional security.

However, the task of retaining leading positions where possible and keeping them for years still does not seem utopian to a significant part of the American elite. It is fueled both by the fact that it is intercon- nected with the maintenance of the power of significant groups of economic and political interests not only in the United States itself, but also of transnational elites in many regions of the world, and by the logic of the existence, development, and reproduction of very powerful state institutions. Therefore, it is highly likely that for several more decades the American leadership will undertake both systematic and sporadic efforts to preserve the superiority of the United States in the long term and to break away from potential competitors, even if the logic of solving this ideological task contradicts American interests.

Despite the fact that the means to achieve this long-term goal under Democratic Presidents B. Obama (2009-2017) and J. Biden (since 2021) differ significantly from those resorted to by the Republican administration of D. Trump (2017-2021), the general logic of defining American interests and actions has not undergone significant changes. The United States strives to maintain its primacy simultaneously in the financial and economic, international political, scientific, technological and innovation, military and power, and ideological spheres, as well as in all types of activities of global importance. However, the forms and methods of achieving this goal vary considerably. The erosion of the foundations of American leadership is not happening at the pace predicted by many political publicists both in the United States and beyond.

\section{US POSITION IN THE WORLD ECONOMY}

The United States has successfully maintained its special status as the world's most powerful economya market attractive to exporters and investors from other countries. According to the IMF data for 2020 , the US GDP amounted to $\$ 22.68$ trillion at current prices; China's, to $\$ 16.64$ trillion (plus Hong Kong's $\$ 0.36$ trillion); Japan's, to $\$ 5.38$ trillion; Germany's, to $\$ 4.32$ trillion; India's, to $\$ 3.05$ trillion; and Russia's, to $\$ 1.71$ trillion [6]. The United States continues to retain significant market and political potential to influence pricing processes in the global oil market and the largest regional gas markets. The "shale revolution" that took place in the late 2000s and early 2010s allowed the United States not only to ensure its energy independence to a large extent but also to become one of the world's largest exporters of crude oil and gas [7].

A significant superiority of the United States remains in the field of reproduction of highly skilled labor resources and human capital in general, ${ }^{2}$ in the creation of innovative goods and services, and in the development of basic and applied science. US national

\footnotetext{
${ }^{2}$ US national spending on education in 2019 amounted to $6.2 \%$ of GDP ( $\$ 4000$ per capita), and on health spending, to $17.1 \%$ of GDP (per capita spending exceeded $\$ 11000$ ). All indicators are calculated by IMEMO RAN according to the World Bank Group, WDI Database.
} 
spending on R\&D in 2019 amounted to $\$ 621$ billion (2.9\% of GDP); that of China, $\$ 322$ billion (2.2\% of GDP); that of Japan, $\$ 165.8$ billion (3.3\% of GDP); that of Germany, $\$ 119.5$ billion (3.1\% of GDP); and that of Russia, $\$ 18.7$ billion (1.1\% of GDP). ${ }^{3}$

The United States retains dominance in world finance: the dollar remains the key global reserve currency, and its positions are solid-over $40 \%$ of world settlements in trade in goods and services are denominated in dollars, as well as more than $62 \%$ of the reserves of the central banks of the world's leading powers. The US Federal Reserve System-the American national regulator-affects the entire world financial system; indirectly, national banking systems of other countries, their monetary policies, exchange rates, and rates of national banks. American investment funds and transnational banks remain the largest investors and players in global stock markets [8]. The notions of some economists that the dollar may have alternatives and that its role as the most popular global currency will sharply decline still do not find confirmation. Only a little more than $20 \%$ of the reserves of the central banks of the world are kept in euros; $5.7 \%$, in Japanese yens; and 4.4\%, and in British pounds; the Chinese yuan accounts for $2 \%$ [9].

Many experts both in the US and abroad while analazing perspectives of American global economic leadership are regularly raising the issues of national financial system disbalances, including the growing national debt and the budget deficit. According to the 2021 data of the Budget Committee of the United States Congress, the budget deficit is $\$ 2.3$ trillion and exceeds the annual GDP of the United States. Its growth was facilitated by the unprecedented measures taken by the Trump administration to overcome the socioeconomic consequences of the COVID-19 pandemic and stimulate the growth of the American economy. However, it is highly likely that already in 20222023 , if the epidemic situation normalizes, economic growth resumes (in fact, it began in the 4th quarter of 2020), and tax revenues increase, the budget deficit will decrease. Its very presence does not violate the stability of the economy. On the contrary, the United States has used it for many decades as an important tool to stimulate economic growth and social investment. Scientific literature and journalism consider the US national debt, which in mid-2021 is more than \$28 trillion, an even more significant imbalance of the American economy [10]. However, the dramatic nature of this problem, which is certainly of a systemic nature, should not be exaggerated. Only in the event of a new crisis comparable to the crisis of 2008-2010 might the US government debt become an important negative factor for the American securities market. The gigantic national debt is provided in full by state property and other assets, and by and large, by the

\footnotetext{
${ }^{3}$ Indicators calculated by IMEMO RAN according to the World Bank Group, WDI Database.
}

entire American economy, including its transnational part, and cannot be claimed by either external or internal creditors at a time, even in any significant part. It is placed in government bonds and other securities with various maturities.

In addition, the structure of the national debt itself and the composition of its holders ensure its stability and security for the US economy as a government instrument to stimulate economic growth and development. The largest holder of US government debt is the monetary regulator represented by the Federal Reserve System. Holders of a significant part of government debt are also US federal funds, for example, the social security fund, pension funds that guarantee the safety of their assets with the help of government securities, US states and cities, as well as other private legal entities and individuals within the United States-banks and insurance companies. Despite the fact that the external part of the national debt is significant, accounting for about $25 \%$, the countries that are the holders of US government securities are themselves interested in the stability of the instruments in which their funds are placed. Note that for many years the PRC has retained the position of the second largest US creditor (the PRC accounts for $\$ 1.09$ trillion, and separately Hong Kong, for $\$ 223.9$ billion) after Japan ( $\$ 1.27$ trillion) in terms of the volume of invested funds, regularly buying American government bonds and other securities [11].

However, in the sphere of trade in goods and services, including high-tech ones, the position of the United States is changing dynamically. The leading economies of Western Europe and Japan since the 1970s, the Republic of Korea since the 1990s, and the PRC since the end of the 2010s-early 2020s, while maintaining deep economic interdependence with the United States in the field of technology, investment, and access to the American market, have been able to form a competitive potential in many markets for goods and services, including innovative ones. They have become significant players in international trade and have occupied high positions in the international division of labor, and the multinational corporations (MNCs) associated with them have begun to play an important role in global value chains. Due to the significant concentration of financial resources, not only countries associated with the United States by allied relations in the military-political sphere but also China have become large exporters of foreign direct investment [12].

American power is enormous in the formation of new high-tech markets. However, US MNCs have already faced increasing competition from European, Chinese, and South Korean companies. Difficult compromises are being worked out with the US allies, such as Germany and France, as well as between the United States and the EU, Japan, and the Republic of Korea, which make it possible to regulate competition 
[13]. During the Trump administration, a trade war existed between the United States and China, which stimulated many experts to talk about the possibility of decoupling the interdependence between the two largest economies in the world. However, the only area in which it was possible actually to carry out delimitation was trade in high-tech goods, especially those related to dual-use technologies; to a certain extent, this process has affected a number of areas where Chinese manufacturers have already begun to oust American companies even from the domestic market of the United States itself. The dynamics of trade in hightech products between the United States and China has been steadily declining since 2019: according to the Office of the US Trade Representative, in 2020, Chinese exports of such products to the United States fell to $\$ 119$ billion (\$174 billion in 2018), and US exports to China decreased from $\$ 39$ billion in 2018 to $\$ 29$ billion at the end of 2020 [14].

The European Union, China, Japan, and the Republic of Korea have become active players in the global innovation markets due to increased $R \& D$ costs [15]. Chinese companies were able to rise to new heights in the hierarchy of the international division of labor, creating direct competition, including those MNCs of American origin, the investments and technologies of which in the previous period allowed them to create a development basis for them. This is especially evident in areas such as microelectronics, telecommunications and communications, the creation of computer technology, the IT sector, and the development of digital platforms [16]. The Biden administration continues to take steps in the direction that was clearly outlined by its predecessor D. Trump: to create openly and systematically technological, trade, financial, and other restrictions on Chinese companies operating in these sectors. The most revealing victims of such a policy in 2019-2020 were Huawei and ZTE, and from the beginning of 2021, Xiomi, SMIC, and Phytium. Washington's practice of using noneconomic methods to counter technological and economic competitors on a global scale will expand in the coming years, and China is their strategic goal. The United States has already begun to involve its allies and partners actively in this policy-the EU countries, Canada, Japan, and Taiwan, which, however, seek to maintain trade and other ties with Chinese high-tech companies and are not ready to assist the Americans in everything.

Another global advantage of the United States, which allows American companies to be key players in many markets for goods and services and to remain key investors in many regions of the world, has for many decades been the existence of production and other infrastructure of transnational capital of American origin outside the territory of the United States. The functioning of this "second economy" of the United States relies on enormous transport, infrastructure, and communication opportunities: free access to the three oceans, US leadership in the emergence and development of the Internet, and the ability to always protect its trade and investment interests with the help of military force. In the next decade, neither China nor any other country will be able to create anything comparable or significantly limit American transport and logistics capabilities.

\section{CHALLENGES TO THE US LEADERSHIP IN THE CHANGING GLOBAL POLITICAL AND SECURITY ENVIRONMENT}

Global political and security posture of the United States is changing more dynamically than the economic one. The United States remains a global power, relying on allies in Europe and Asia, as well as partners in all regions of the world, exerting a significant influence on the principles and mechanisms of activity of most regulatory international political and economic institutions. However, compared with the situation after the end of the Cold War, the collapse of the Soviet Union, the liquidation of the Warsaw Pact Organization and the Council for Mutual Economic Assistance, and the ideological and political defeat of the international communist movement, the global political, ideological, and value influence of the United States in the world has already significantly decreased and in many features continues to decline. This is partly due to the disillusionment of elites and societies in many countries with the American version of liberal values and political principles, which in the 1990s and early 2000s served as a kind of model for organizing a political system for them. This path has been traveled by Russia and Turkey, partly by a number of Eastern European countries, primarily Poland and Hungary. The proselytism of the American policy of spreading democracy, which often covered up the foreign policy interests and aspirations of the United States, became one of the sources of discrediting the ideological and political influence of the United States in the world [17]. Attempts to revive the global ideological significance of American values and principles are now being undertaken by the Biden administration, which has returned to the old concept of the "community of democracies" and the institutions it creates as a value-oriented alternative to universal institutions. It is highly likely that the idea of a global struggle of "market liberal democracies" led by the United States against "nonmarket nondemocracies" (primarily Russia and China) will acquire a new breath in US foreign policy.

The changes taking place in the world, as well as internal trends in the social, economic, and political development of the United States have created conditions for the American state apparatus, elite, and scientific expert community to realize and set the task of developing a new model of interaction with allies, partners, and opponents of Washington. This logic began the search for practical means of maintaining 
the US leading positions in various fields of activity, as well as new strategic guidelines for American foreign and security policy. The foreign policy establishment and the US leadership always formulate such goals not only within the framework of a pragmatic understanding of national interests but also in a value modalityin terms of a global "mission" to spread the set of values that underlie American statehood.

Despite the decline in political, ideological, and value influence, America retains an unconditional priority in the military sphere: first of all, in the possession of the most powerful high-tech military potential, backed up by a system of bases and other military infrastructure removed from the territory of the United States. Only in the nuclear missile sphere is parity with Russia preserved. The extension of the Treaty between the United States of America and the Russian Federation on Measures for the Further Reduction and Limitation of Strategic Offensive Arms (NEW START) created guarantees that, at least with regard to strategic nuclear forces (SNF), Russia and the United States will maintain their potentials at the level of 1550 warheads and 700 delivery devices for another five years. Although the United States is significantly superior to Russia in other types of weapons and military equipment, it is the strategic offensive weapons-the nuclear triad-that remain the means that so far reliably guarantees the maintenance of parity in relations between the two powers. Russia possesses the scientific and technological groundwork and the material and technical base that allows it to maintain its SNF at a level comparable to the American one, at least for the period of the NEW START regime. Perhaps it will be possible to achieve this in the longer term if a new treaty regime is created with comparable quantitative ceilings and qualitative restrictions. It would be extremely difficult for Russia to be economically involved in a new arms race if Washington decides to withdraw from the NEW START Treaty and sharply build up its SNF in combination with the deployment of other systems that upset the balance of power. However, such a scenario appears unlikely under the Biden administration. The current distribution of priorities in the US military budget assumes a gradual SNF modernization without a sharp increase in the number of nuclear warheads and delivery vehicles. However, if Washington continues the course of simultaneous military containment of the Russian Federation and the PRC, such a need may arise.

The United States and Russia have acquired more and more types of weapons that erode strategic stability in Russian-American relations: hypersonic and gliding missile systems, nonnuclear strategic missiles, high-precision conventional weapons, and long-range aeroballistic missiles, including nuclear weapons, autonomous combat unmanned aerial and naval systems capable of carrying nuclear weapons. Technologies of cyberattacks and electronic warfare are also being developed [18]. However, none of these types of weapons and military equipment can significantly affect the balance of strategic forces between Moscow and Washington at least in the next five years. The main factor capable of dramatically destabilizing strategic stability and significantly aggravating relations between Russia and the United States is the deployment of nuclear-armed American medium-range missiles in Europe and Pacific Asia, which was planned by the Trump administration when deciding to withdraw from the Intermediate-Range Nuclear Forces (INF Treaty).

The PRC has a significantly lower strategic nuclear potential, but the People's Liberation Army of China is armed with ground-based intermediate and shorterrange missiles, which neither Russia nor the United States possesses [19]. They were liquidated after the conclusion of the INF Treaty in 1987. Despite the fact that the United States launched work on the creation of such systems immediately after the withdrawal from this treaty, and probably even before it, several years will pass before the introduction of these systems into service. For Beijing, medium-range missiles, including nuclear-armed missiles, are a key tool in countering American military power in the Asia-Pacific region (APR): these weapons are capable of completely neutralizing the US Navy and destroying American bases in the region in case of war. The withdrawal of the United States from the INF Treaty was aimed primarily at containing China. The deployment of ground-based medium-range missiles in Pacific Asia could allow Washington to supplement its strategic nuclear deterrent with intermediate (medium) and shorter range missiles. The deployment of such systems in Europe would significantly reduce the flight time to the territory of Russia and reduce the survivability of its SNF, as well as command and control mechanisms. However, in either case, the decision to deploy such systems will mean a sharp increase in military-political tension.

A sharp increase in China's military budget, which doubled from 2009 to 2019, reaching \$266.9 billion, almost $27 \%$ of the US military budget ( $\$ 718.6$ billion ${ }^{4}$ ), has long been a matter of concern and apprehension of the Pentagon. The development by China of a wide range of weapons and military equipment, including systems aimed at containing American military power in the APR and on a wider scale in the long term, allow the American military to assess China as its second most important enemy. In the coming years, the People's Liberation Army of China is capable of becoming the number one military enemy of the US Army; with the exception of SNF, it has already become one. Over the next 10-15 years, China's military potential may become comparable to the United States in a number of weapons and military equipment, as well as in some quantitative and qualitative characteristics of the armed forces. Such predictive

\footnotetext{
${ }^{4}$ SIPRI data by PPP [20].
} 
estimates have already been recorded in American military-strategic documents.

The restoration of Russia's military potential and the growth of the PRC's military capabilities were a factor that played an important role in the understanding by the American political establishment and the military of the new limits to the military power of the United States. In the case of Russia, two things mattered. First, the preservation of Russian strategic offensive weapons was important, which in the event of a military conflict remain the only real source of threat to the security of the territory and the viability of the US military potential. Keeping the military budget at a level of ten or more times lower than the military spending of the United States, Russia managed to modernize the strategic nuclear triad and develop new offensive and defensive systems, including nuclear equipment [21]. Second, the readiness demonstrated by the Russian leadership and the armed forces to be involved in regional conflicts and the use of military force abroad and to conduct large expeditionary operations, showed Washington that the United States no longer has a monopoly on the use of military force (alone or with allies).

The leading positions of the United States in the field of conventional weapons may be shaken in the coming years under the pressure of the growing military might of the PRC. American leadership is still contested primarily in terms of quantitative indicators. For example, the total number of the combat strength of the Chinese Navy in 2019 surpassed the size of the American fleet for the first time. At the beginning of 2021, the United States had 293 warships, while the PRC already had 350 [22]. Strengthening the potential of Russia and China in such promising areas as the creation of hypersonic systems; increasing the effectiveness of missile defense; and developing high-precision conventional long-range weapons, attack unmanned aerial vehicles, and electronic warfare systems, as well as other advanced types of weapons and military equipment, can limit American superiority in several areas already in the medium term. Despite the huge US military budget and significant investments in military and dual-use R\&D set by the Trump administration, apparently, the still urgent task of simultaneous political and military containment of Russia and China in the long term may be difficult for Washington to fulfill.

However, it should be borne in mind that the factors limiting the US ability to project power on a global scale may not only be external. As a result of the wars in Afghanistan and Iraq, noticeable groups of opponents of the active use of the US armed forces abroad have formed in American society and the political elite. These pressure groups and their influence in Congress, the media, and society will in the coming years remain a factor holding back new military initiatives of both Democratic and Republican administra- tions, with the exception of targeted military operations using aircraft, including drones. Despite the US readiness for widespread use of remote means of warfare, such as the use of bombers, air- and sea-based cruise missiles, and other high-precision systems, which was already confirmed by the Biden administration in February 2021 in Syria, the likelihood of a massive use of military force by Washington "overseas," especially involving ground operations, dropped sharply.

Today, the United States seeks to address many military challenges through hybrid operations. They imply only a limited use of military force in different proportions with other means (depending on the nature of the enemy and the specific goal). For example, the actions of special units and special operations can be supplemented by the use of private military companies and other nongovernmental players, as well as cyberattacks and information-psychological, financial-economic, and other measures of influence. Sanctions and other economic restrictive measures are an important way to enhance the economic, political, and psychological effects of hybrid operations. The hybrid format allows for a systemic impact on the enemy without engaging in direct military confrontation or in a confrontation with the use of military force on a limited scale [23]. Over the years, the United States has perfected this toolkit alongside military means of "spreading democracies" and changing regimes.

Reducing the possibilities of Washington's use of military force without the risk of major military conflicts with the involvement of leading regional and world powers, including Russia, and, in the future, the PRC, as well as internal political factors, in the coming years will entail an expansion of the practice of hybrid operations. They will increasingly be supplemented by other means of pressure in essence but nonmilitary in form, the most important of which are financial, economic, and other sanctions. It can be expected that the Biden administration will be more successful than the Trump administration in attracting European allies to such campaigns.

\section{CHINA AND RUSSIA IN THE US GLOBAL STRATEGY}

At the level of the foreign policy attitudes of most American strategic documents of recent years, the position of a significant part of the US political elite, regardless of party affiliation, has portrayed the main opponents and competitors of the United States as primarily China and Russia. Over the past six-to-seven years, there has been a gradual transition of Washington at the conceptual political level, as well as in the field of military planning, to a strategy of double deterrence-the PRC and the Russian Federation. 
The 2015 National Security Strategy and other strategic documents adopted by the Obama administration still had a different approach to Russia and China. Russia was repeatedly called an "aggressor" that violated the territorial integrity of Ukraine and potentially threatened other neighboring countries [24, pp. 2, 4, 25], and China was designated as a "growing power" and an important partner of the United States, which caused Washington's concern only in connection with the ongoing military modernization [24, pp. 1, 4, 24]. However, already in the 2017 Strategy adopted by the Republican administration of Trump, the accents are placed differently. China and Russia are openly called "rivals" of the United States, and it is they who are indicated when the text of the Strategy mentions American "opponents." The characteristics that are given in the document to both Russia and the PRC are significantly toughened: both states are described as "revisionist powers" that oppose American interests and values [25, pp. 25], strive to spread their influence on a global scale, and carry out aggressive preparations and actions in relation to the national security of the United States and its allies in Europe and Asia [25, pp. 2, 27, 45]. Thanks to the bipartisan consensus, which has largely developed on the need to contain Russia and China simultaneously, this approach is already being developed at the level of the first strategic documents of the Biden administration.

The Interim National Security Review, adopted in March 2021, which was prepared as an alternative to the Trump Administration's National Security Strategy, not only reproduces the previous formulations regarding Russia and China, but, moreover, characterized both our countries as "authoritarian" opponents seeking to question the security of the United States and its allies [26, pp. 6, 8, 14]. At the same time, the document speaks of the need for a dialogue with Russia and China on arms control and other security issues [26, p. 13].

One cannot expect that Washington's strategic assessments and approaches to Russia will change in the coming years. Relations between Russia and the United States have acquired the character of a stabilized conflict, in which each of the parties is not interested in its military development and transition to the military stage, but is ready for political escalation at any moment. Relations began to acquire the character of not so much competition as confrontation in certain areas from the beginning of the 2010s and deteriorated precipitously in connection with the Ukrainian crisis in 2014, spreading to ever new spheres of interaction, including the military planning of the United States/NATO and Russia.

In subsequent years, especially after 2016, when some representatives of the American special services and part of the political establishment accused Russia of interfering in the US presidential elections, rela- tions between the two countries deteriorated even more and stabilized in this state. Despite the fact that Moscow and Washington manage to reach compromises on certain issues, in general, the United States continues its policy of strategic containment of Russia, not only militarily but also politically, economically, and technologically.

The United States has taken a number of systemic measures to exert political and psychological pressure on the Russian economy, society, business, and political elite through financial, economic, technological, and political sanctions and other restrictions. Such measures began to be taken even before the Ukrainian crisis and the annexation of Crimea to Russia: the first step here was the Magnitsky Act adopted in December 2012, but since 2014 the sanctions have been consistently expanded by the administrations of Obama, Trump, and Biden. Despite the statements by representatives of the American leadership about the possibility of lifting the sanctions in the event of certain actions by Moscow, by the end of 2016 it became obvious that in reality their introduction had nothing to do with Russian politics, they were systematic and longterm. The sanctions are primarily aimed at limiting the development opportunities of the industries most significant for Russia's presence in foreign markets: the fuel and energy and defense industrial complexes, the metallurgical industry, the financial sector, and the promising IT sector. The purpose of these actions is to reduce the global competitiveness of Russia, create conditions for the emergence of long-term negative consequences and socioeconomic imbalances, and influence the internal political processes in Russia and its foreign policy. During the Trump administration, American sanctions received a long-term legislative fixation and further development after the adoption in 2017 of the Countering America's Adversaries Through Sanctions Act. These steps were supported by an anti-Russian information campaign in the American and global media, as well as by Washington's actions aimed at limiting cooperation with Russia by third countries, including American allies.

The confrontation between Russia and the United States is based not only on the opposing interests of the two countries in many areas and regions of the world but also on significant differences in the vision of the emerging world order by the political elites of both powers, the hierarchy of its actors, and the principles of organizing relations between them. These differences relate primarily to understanding the role and status of the United States and the Russian Federation in the world. In the minds of the American elite, regardless of its party affiliation, a stable negative image of Russia has formed as a revanchist country that lost the Cold War, but did not accept its position, and turned into a source of challenges and threats to the global leadership of the United States, as well as its security and interests in various regions of the world. 
The strategic goals of countering Russia in the European direction are especially important for Washington. The United States cannot allow further deepening of trade, investment, humanitarian, and other ties between Russia and the EU. In previous years, the growing interdependence of Russia and the EU in the energy sector was viewed by Washington as a threat to American influence in Europe and the energy security of its allies. During the Trump administration, the Russian presence in the European gas market began to be perceived as a competitive challenge in the context of expanding the export of American liquefied natural gas to Europe, as well as gas produced by American companies in the Middle East. This logic is the basis for Washington's positions and actions regarding the implementation of the Nord Stream 2 project and other Russian initiatives in the field of developing cooperation with the EU countries in the energy sector.

The factor of the "Russian threat" remains one of the most important means of maintaining allied solidarity and military-political consolidation in NATO. The United States opposes Russia's having special spheres of interest and influence in the post-Soviet space. During the Trump administration, Washington's attention to the post-Soviet space decreased slightly, but with the arrival of Biden it is likely to intensify, given the very tough position of his administration members on the crisis in eastern Ukraine.

Throughout the course of the Trump administration, Russian-American relations did not improve and continued to degrade in a number of important areas.

First, the military security and arms control situation remains difficult. Under Trump, the United States consistently reduced opportunities for bilateral dialogue, as well as for the preservation and development of mutual obligations and restrictions. In 2018, the United States withdrew from the Joint Comprehensive Plan of Action on Iran's Nuclear Program (2015); in 2019, from the Treaty on the Elimination of Intermediate-Range and Shorter-Range Missiles (1987) and announced plans to create and deploy appropriate missile classes in Europe and the APR; and in 2020, from the Open Skies Treaty (1992). The Trump administration nearly thwarted the NEW START extension process. Despite the fact that one of Biden's first steps was to extend the NEW START Treaty for five years without preconditions, the prospects for preparing the next comparable agreement are not yet visible.

Second, sanctions and other restrictive measures were increased. The number of sanctions imposed during the Trump administration (52 rounds) exceeded those that were adopted under Obama (40 rounds). The Biden administration in the first months adopted several more sanctions in the financial, political, and technological spheres. Thanks to the legislative framework formed by the Congress, the possibilities for the introduction of targeted sanctions directly by ministries and departments have expanded. Washington's pressure on European allies and other partners has increased with demands to comply with US sanctions, which are given an extraterritorial nature. In the next few years, Washington's lifting of anti-Russian sanctions is extremely unlikely, but American government departments have tools for their relatively flexible application: their temporary lifting can be motivated by US national security interests, which are often interpreted quite broadly.

Third, the contradictions between Russia and the United States are likely to grow in the struggle for regional gas markets, especially for the European market and, in the long term, for the Asian. In addition, the United States, which has become a major oil exporter, like Russia and Saudi Arabia, as well as a number of other exporting countries, is interested in maintaining the weighted average price of crude oil. This determined Washington's readiness to reach a compromise with Moscow and Riyadh on the oil price during the Trump administration. Apparently, these informal agreements will remain in force under Biden. However, this coincidence of interests of Russia and the United States is tactical. The Biden administration, taking into account the interests of its European allies, is sending signals about a possible softening of its position on Nord Stream 2, but in the long term, the United States will not abandon its goal of limiting Russia's export opportunities in world energy markets.

In the coming years, relations between Russia and the United States will experience an increasing impact of domestic and international factors, and not necessarily directly related to bilateral relations. Cooperation between the United States and China in the trade, economic, and military-political spheres will be of particular importance. Despite the relative softening of the political rhetoric of the Biden administration, in comparison with the Trump team, the basis for the growth of economic, technological, and geopolitical competition with elements of regional military-political confrontation, while maintaining interdependence in the financial and economic sphere, has formed in US-China relations. This interdependence makes the PRC more vulnerable than the United States if it is violated. Beijing is well aware of this; not only Chinese business but also the leadership of the PRC and the CPC are aware of the risks of further deepening confrontation and rupture with America, despite decisions to develop the domestic market and attempts to diversify the sales markets.

For Russia, in the foreseeable future, the dynamics of US relations not only with the PRC but also with the EU, as well as between the leading European powers and China, is of increasing importance. Another important area is Russia's interaction with India and the ASEAN countries, the importance of which in the 
transformation of the economic and political world order will only grow. In the coming years, Washington will try to drag India into an alliance based on opposing China. The United States will most likely seek to influence the Indian leadership in order to limit cooperation with Russia, but there remains considerable room for maneuvering, which implies a significant intensification of Russian policy in the Indian direction.

Despite all the difficulties, contradictions, and a high level of conflict, the agenda of Russian-American relations still includes topics of mutual interest and opens up opportunities for working out compromises with the Biden administration. Among them, the following issues are of particular importance:

- arms control and further steps to maintain strategic stability and reduce military danger, including developing confidence-building measures, preventing incidents, and resolving crisis situations;

- nonproliferation of weapons of mass destruction and their delivery vehicles;

- counteraction to international terrorism and religious and ideological extremism;

- fight against dangerous infectious diseases and their consequences;

- prevention of natural and man-made disasters and overcoming their consequences;

- preserving natural ecosystems and combating climate change;

- ensuring safety at sea and in outer space and reducing cybersecurity risks.

From the point of view of the Russian-American interaction, the dialogue not only between the foreign policy and military departments but also between the scientific and expert communities of the two countries, as well as the so-called second track diplomacy, is of particular importance. Despite the sanctions and other restrictions, a significant part of American scientists, research centers, and universities are willing and interested in maintaining ties with Russian research organizations. Moreover, a number of American social scientists have consistently and openly advocated improving relations between the two countries in some areas. As a rule, the position of experts is conditioned by their ability, unlike officials and politicians, to think for many years and even decades ahead. They understand that the world order is undergoing a stage of deep transformation and, taking into account the emerging trends, doubt the usefulness for the United States of a long-term comprehensive confrontation with Russia.

\section{FUNDING}

This paper is published within the project "Postcrisis World Order: Challenges and Technologies, Competition and Collaboration" of the Ministry of Science and Higher Education of the Russian Federation for large scientific projects on priority areas of scientific and technological development (agreement no. 075-15-2020-783).

\section{REFERENCES}

1. C. Krauthammer, "The unipolar moment," Foreign Aff. 70 (1), 23-33 (1991).

2. F. G. Voitolovskii, V. Yu. Zhuravleva, and A. R. Borisova, "Approaches of Russia and the US to global governance and UN reform," Puti Mir. Bezop., No. 1, 7-23 (2016).

3. S. V. Kislitsyn, Peace through Strength: Foreign Policy Ideology and Practice of American Neoconservatism (Ves' Mir, Moscow, 2020), pp. 118-122 [in Russian].

4. S. Almukhtar and R. Norland, "What did the U.S. get for \$2 trillion in Afghanistan?," New York Times, Dec. 9 (2019). https://www.nytimes.com/interactive/2019/12/09/world/middleeast/afghanistan-warcost.html.

5. N. Crawford, "The Iraq War has cost the US nearly \$2 trillion," Military Times, Feb. 6 (2020). https://www.militarytimes.com/opinion/commentary/2020/02/06/the-iraq-war-has-cost-the-us-nearly-2-trillion/.

6. IMF GDP, current prices. https://www.imf.org/external/datamapper/NGDPD@WEO/OEMDC/ADVEC/WEOWORLD/US.

7. S. S. Dmitriev, "US energy strategy: Correction of priorities," Mir. Ekon. Mezhdunar. Otn., No. 3, 13-23 (2014).

8. US Economy in the 21st Century: Challenges and Development Trends, Ed. by V. B. Supyan (Ves' Mir, Moscow, 2018), pp. 35-36 [in Russian].

9. A. Siripurapu, "The dollar: The world's currency," CFR Backgrounder, Sep., 29 (2020). https://www.cfr.org/backgrounder/dollar-worlds-currency.

10. Peterson Foundation National Debt Clock. https://www.pgpf.org/national-debt-clock?utm_term.

11. Major foreign holders of treasury securities. Department of the Treasury/Federal Reserve Board, March 15, 2021. https://ticdata.treasury.gov/Publish/mfh.txt.

12. US-China: The Struggle between Two Strategies and Practices of World Leadership, Ed. By I. Ya. Kobrinskaya and I. L. Vartazarova (IMEMO RAN, Moscow, 2018), pp. 27-28 [in Russian].

13. I. S. Korolev, "American centrism and multipolarity in the global economy (trade, political and financial aspects): Analysis and forecast," Mir. Ekon. Mezhdunar. Otn., No. 1, 12-22 (2020). https://doi.org/10.20542/afij-2020-1-12-22

14. Office of the US Trade Representative. U.S.-China trade facts. https://ustr.gov/countries-regions/chinamongolia-taiwan/peoples-republic-china.

15. Innovative Competition, Ed. by N. I. Ivanova (Ves' Mir, Moscow, 2020), pp. 13-18 [in Russian].

16. I. V. Danilin, "US-China technology war: Risks and opportunities for China and the global technology sector," Sravnit. Polit., No. 4, 160-176 (2020). 
17. A. A. Davydov, "The concept of "promoting democracy' in US foreign policy," Chel. Soobshch. Upr., No. 4, 22-43 (2017).

18. Arms Control in the New Politico-Military and Technological Conditions, Ed. by A. G. Arbatov (IMEMO RAN, Moscow, 2020), pp. 36-73 [in Russian].

19. V. Esin, "Nuclear forces of the PRC: Current state and development," Russ. Am. 21st Cent., No. 2 (2020). https://rusus.jes.su/s207054760010387-2-1/.

20. SIPRI Military Expenditure Database. Data for all countries from 1988-2019 in constant (2018) USD. https://www.sipri.org/sites/default/files/Data\%20for\%20all\%20coun-

tries\%20from\%201988\%E2\%80\%932019\%20in\%20co nstant\%20\%282018\%29\%20USD.pdf.

21. Military-Economic Development and Security, Ed. by L. V. Pankova and O. V. Gusarova (Ves' Mir, Moscow, 2020), pp. 107-109, 113-122 [in Russian].

22. B. Lendon, "China has built the world's largest navy. Now what's Beijing going to do with it?," CNN, March 6
(2021). https://edition.cnn.com/2021/03/05/china/china-world-biggest-navy-intl-hnk-ml-dst/index.html.

23. V. Konyshev and R. Parfenov, "Hybrid wars: Between myth and reality," Mir. Ekon. Mezhdunar. Otn., No. 12, 56-66 (2019).

24. National Security Strategy of the US-2015, February. https://obamawhitehouse.archives.gov/sites/default/files/docs/2015_national_security_strategy_2.pdf.

25. National Security Strategy of the US-2017, December. https://trumpwhitehouse.archives.gov/wp-content/uploads/2017/12/NSS-Final-12-18-20170905.pdf.

26. Interim National Security Strategic Guidance, March, 2021. https://www.whitehouse.gov/wp-content/uploads/2021/03/NSC-1v2.pdf.

Translated by B. Alekseev 